found: that Java indigo can tolerate wide changes in reaction, growing in Bihar in soil at $p \mathrm{H} 8.7$ and in Assam at $p \mathrm{H}_{5} 4$. It, however, does much better in the latter for various reasons.

In the British Isles it has been found that the yellow stonecrop, Sedum acre, flourishes in soil from $\mathrm{pH}_{7}$ to 8 or over, whereas the white $S$. anglicum. may be growing at from $p \mathrm{H} 6.8$ to 5.1 , possibly slightly outside these limits. Plants which are by some regarded as typical species of limestone districts nay be found elsewhere provided the soil reaction is suitable; thus Salvia verbenaca grows between $\mathrm{pH}_{7}$ and 8 , Crithmum maritimum around $p \mathrm{H} 8$, and Cochlearia danica from $\mathrm{pH}_{7.5}$ to 8 , possibly over it, much the same range being occupied by Linaria cymbalaria; for Centranthus ruber values from $\mathrm{pH}_{7.4}$ to 8.8 have been obtained. The common gorse, Ulex europaeus is usually found on acid soil; in seven cases where it was observed growing in abundance the reaction was $p \mathrm{H} 6.8$ to 5.4 , but one plant was found at $p \mathrm{H} 8 . \mathrm{I}$, one at 8.2 , and three or four at 8.6. In other cases the soil was probably alkaline, but was not tested.

The sea pink, Armeria maritima, may be found between $p \mathrm{H} 6.8$ and 8.2 , but the typical sand-dune: plants, Ammophila arenaria, Euphorbia Paralias, Salsola Kali, are found only in the neighbourhood of $p \mathrm{H} 8$.

Moorland plants, Erica tetralix, Anagallis tenella, Drosera rotundifolia, Jasione montana, etc., are commonly found at $\mathrm{H}_{5.5}$ to 5 , or thereabout, but the limits are certainly wider.

The accumulation of data of this type is of necessity a slow process, but one cannot fail to be impressed by the fact that the presence or absence of a plant in a given locality stands in close relation to the hydrogen-ion concentration of the soil. Plants may survive, or even do well, in cultivation outside their normal limits, but in free competition with their neighbours the soil reaction is often the deciding factor-always, in fact, if the divergence from the normal $p \mathrm{H}$ value for the species is sufficiently great.

Considerable changes in the soil reaction may be met with in quite a short distance. Thus on crossing a road at Youghal, Co. Cork, one passes from a soil of about $p_{7} \mathrm{H}_{7}$, with Salvia verbenaca and Ononis arvensis, to an acid soil, $p \mathrm{H} 6.8$ to 6.4 , with gorse, and in the wet parts Iris pseudacorus and bog-cotton. This, in turn, passes into sandy pasture and sand dune, the latter giving about $p \mathrm{H8}$. Again, near Cawsand, in Cornwall, gorse is plentiful on the felsite soil at $\mathrm{pH}^{6} \cdot 4$ to 5.4 , but absent from the adjacent, and similarly situated, soil of the Staddon Grits, which normally gives $p \mathrm{H}_{7}$ to 7.8 .

It appears as if corresponding differences are shown by water-plants and fresh-water algæ, the upland waters which are very slightly acid or almost neutral favouring the desmids. There is much room for further work along these lines.

August 30 .

W. R, G. Atkins.

\section{"Smoky" Quartz.}

THE deeply tinted varieties of quartz, such as "smokv" quartz and the yellow or Madagascar variety, are generally transparent in the infra-red region of the spectrum to the same extent as clear rock-crystal, as may easily be demonstrated with the aid of a thermopile and galvanometer. I wish to suggest that a very simple physical explanation of this property may be offered. As has been emphasised in a paper by Prof. R. I. Strutt (now Lord Rayleigh) in the Proceedings of the Royal Society for 1919 , these varieties of quartz are really optically turbid media, the opacity arising from the scattering of the radiations in their passage through the crystal by a cloud of small particles present as inclusions. Since scattering of this kind is effective in inverse proportion to the fourth power of the wave-length, it can easily be seen why the longer heat-waves can traverse the crystal without appreciable loss. Some photometric observations which I have made of the relative transparency of the yellow and colourless varieties in different parts of the spectrum support this explanation.

In the paper just quoted Rayleigh has described the very beautiful and striking effects that arise owing to optical rotatory dispersion when a strong beam of polarised light is sent through a block of smoky or yellow quartz in the direction of the optic axis; the track of the beam, as made visible by the scattering particles and observed in a transverse direction, shows bright and dark bands if monochromatic light be used, and alternations of colour if the incident beam is of white light, the effect being due to the fact that the scattering particles themselves act as analysers of the light incident on them. I find that the phenomenon discovered by Lord Rayleigh can be very prettily shown in another way which is also instructive. A thin, flat sheet of unpolarised white light may be sent through the crystal in a direction transverse to the optic axis, and the track of the beam observed in $a$ direction parallel to the optic axis through a Nicol. In this case the scattering particles act as polarisers, and the scattered light suffers a rotatory dispersion of its plane of polarisation in traversing the quartz along the optic axis before reaching the observer's eye. Hence the whole track of the beam as seen through the observing Nicol appears coloured, the tint fluctuating periodically with the thickness traversed as the block is moved to and fro in the line of sight or when the analysing Nicol is rotated.

Rayleigh has shown in his paper that the track of a beam of light traversing a beam of transparent colourless quartz can be successfully photographed. I find that by using a concentrated beam of sunlight it is possible visually to detect the Tyndall blue cone even in this case. Its intensity, however, is exceedingly: small.

22. Oxford Road, Putney, S.W:ir, September 4 .

\section{Brown Bast and the Rubber Plant.}

IN NATURE of June 16 (p. 499), in a paragraph which announces the discovery by the Botany Department of the Imperial College of Science and Technology that " "brown bast' (the most serious disease of Hevea brasiliensis) is essentially a question of phloem necrosis," it is stated that Sanderson and Sutcliffe have shown that "burrs result from the inclusion of areas of diseased laticiferous tissue in stone-cell 'pockets' formed by the activities of wound cambiums."

It should be pointed out that the presence of latex vessels in the core of nodules (burrs) was first recorded by Bateson (Agric. Bulletin Fed. Malay States, August, I9I3, p. 24), and later corroborated by Richards and Sutcliffe ("Hevea brasiliensis," IgI4, Malay Peninsula Agric. Assoc.), and by myself (Bulletin 28, Dept. of Agric., Ceylon, October, 1916, and Annals Roy. Bot. Gdn., Peradeniya, vol. 6, p. 257, I9I7).

Workers in Java have further confirmed this inclusion of laticiferous tissue as regards the nodules which follow brown bast, and the fact that nodules in the most general case result from the inclusion of areas of diseased laticiferous tissue has been common knowledge in the East for the last five years. That the formation of nodules after brown bast is a secondary

No. 2707 , VOL. IO8] 